\title{
A PROBABLE MATHEMATICAL RELATIONSHIP BETWEEN (Si/AI) RATIO AND (Ca/Si) RATIO ON THE COMPRESSIVE STRENGTH OF AN IRON ORE TAILINGS SAMPLE ARISING OUT OF GEOPOLYMERIC REACTIONS
}

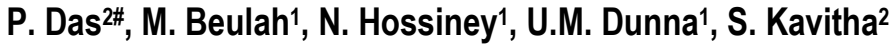 \\ ${ }^{1}$ Christ University, Faculty of Engineering, Kengeri, Bangalore, India \\ ${ }^{2}$ A.C.S College of Technology, Bangalore, India
}

(Received: August 30, 2019; Accepted: October 31, 2019)

\begin{abstract}
In geopolymer reactions, with lime rich compound addition, the strength parameter is dependent on the molar ratios of (Si/Al) and $(\mathrm{Ca} / \mathrm{Si})$, such that (Si/Al) ratio contributes to short period and $(\mathrm{Ca} / \mathrm{Si})$ ratio contributes to long period strength development. In the present study a mathematical model has been proposed to identify the role of each on compressive strength development through exponential mathematical relationship, such that, $\mathrm{N} 1$ is an exponent of (Si/Al) ratio and N2 is an exponent of (Ca/Si) ratio indicating short period and long period strength development parameter respectively, while $\mathrm{C}$ is the compressive strength developed on keeping the samples for different extended time periods. The values of N1 and N2 can be found out by solving linear equations relating (Si/Al) ratio, (Ca/Si) ratio, and compressive strength values of different experimental batch compositions.

Calculated and selected additions of sodium silicate, sodium hydroxide, lime and GGBS in iron ore mine tailing samples indicated that the values of $\mathrm{N} 1$ and $\mathrm{N} 2$ merged with each other after 7 days reaction period, but after 28 days reaction line due to $\mathrm{N} 1$ is found above that of $\mathrm{N2}$. It is concluded that for long period strength development (Si/Al) ratio is more important in comparison to $(\mathrm{Ca} / \mathrm{Si})$ ratio.
\end{abstract}

Key words: Geopolymer; Cement; Durability; Calcium; Mineralogy.

\section{Introduction}

Numerous scientific studies are available on mineral wastes, which are also defined as "residues, tailings and other non-valuable products", obtained after processing of minerals to form mineral products. These waste materials have caused havoc in the past by way of breaching the tailing ponds on mine sites in Hungary and Brazil, causing the destruction of human civilization, and due to the rules and legislations of those countries the mine owners were heavily penalized. Moreover, these wastes are environmentally hazardous and therefore scientific research activities in various laboratories are trying to utilize these wastes for mass civil application. The waste generation from overburden and tailings in iron ore mines is a challenge today, particularly in India, which exports iron ore. Therefore, the present work was carried out in order to utilize the iron ore mines waste from one specific mine in India by way of manufacturing bricks for mass utilization in low cost housing industry. To bring down the cost, geopolymer technology was adopted, which is environment friendly, since it does not require any burning and therefore atmospheric pollution due to carbon burning is also avoided. Geopolymers are produced from the alkali activation of an aluminosilicate source, e.g., fly ash, metakaolin etc. Geopolymeric binders have similar chemical composition as the natural zeolitic materials, but without the extensive crystalline zeolitic structure $[1,2,3]$.

Geopolymers are formed by the polymerisation of individual aluminate and silicate species, which are dissolved from their original sources at high $\mathrm{pH}$

\#Corresponding author: pdas2002@yahoo.com

doi: 10.5937/JMMA1901027D 
in the presence of alkali sources, and the products exhibit high mechanical strengths having the following general chemical formula [Eq. (1)].

$\mathrm{Mn}\left[-\left(\mathrm{Si}-\mathrm{O}_{2}\right) \mathrm{z}-\mathrm{Al}-\mathrm{O}\right] \mathrm{n} \cdot \mathrm{wH}_{2} \mathrm{O}$

where $M$ is the alkaline element, which indicates the presence of a bond; $z$ is 1,2 or $3 ; n$ is degree of polymerization; and $w$ is crystallization of water. Alkali and alkali earth cation (Ca, $\mathrm{Mg}$ ) can be used as a replacement of the alkaline element (M) in the reaction. However, the majority of research was focused on the effect of sodium $\left(\mathrm{Na}^{+}\right)$and potassium $\left(\mathrm{K}^{+}\right)$ions [3] disregarding effect of alkaline earth cations ( $\mathrm{Ca}, \mathrm{Mg}$ ).

In geopolymer formulations it is common to correlate strength parameter with formation of $\mathrm{Si}$ $\mathrm{Al}-\mathrm{H}$ gel, $\mathrm{Ca}-\mathrm{Si}-\mathrm{H}$ gel, and Si-Al-Ca-H gel as well. Identification of these species through analytical studies like SEM, TEM, NMR, E-DAX, etc. are more common. However, these are cost sensitive and laborious. Modern day geopolymer scientists express curiosity as these sophisticated analytical tools were unavailable thousands of years ago, but the marvel of geopolymer massive structures is still intact even after hundreds of years. Theoretically, there should be a direct correlation with mechanical strength and silica content because increasing the amount of silica increases the amount of Si-O-Si bonds, which are stronger than Si-O-Al and Al-O-Al bonds [2]. However, it was found for metakaolin geopolymers that with a Si/Al ratio lower than 1.40 , the geopolymer had a very porous matrix, which led to low compressive strength results. But when the Si/Al ratio was increased over 1.65 the geopolymer showed an increase in strength. This increase was attributed to a homogenous microstructure in the geopolymer. However, it was shown for metakaolin geopolymers that the optimum strength was at an intermediate Si/Al ratio [4]. It was found that the reduction in strength for high Si/Al ratio mixes was the result of unreacted material, which was soft and acted as a defect in the binder phase $[5,6]$.

Past research has also shown that the addition of calcium into metakaolin geopolymers has beneficial results for mechanical properties although its exact role is yet unknown. It has been observed that both geopolymer gel and calcium silicate hydrate form during the reaction process $[6$, $7,8]$. For metakaolin geopolymers, it appears that the alkali hydroxide concentration plays a vital role in determining if $\mathrm{CSH}$ forms in the geopolymer. At low alkali hydroxide concentration, the reaction product favors the formation of $\mathrm{CSH}$, while at higher concentration (above $10 \mathrm{M}$ ) the reaction favors the formation of the geopolymer gel. This difference is due to the fact that the high hydroxyl concentration hinders the $\left[\mathrm{Ca}^{2+}\right]$ dissolution forcing the dissolved silicates and aluminum species to form geopolymer gel. On the other hand, when the $\left[\mathrm{OH}^{-}\right]$concentration is low, the amount of $\left[\mathrm{Ca}^{2+}\right]$ dissolving increases and causes more $\mathrm{CSH}$ to form [7]. Addition of calcium has been observed to accelerate the hardening process and increase the strength for fly ash based geopolymers [9]. It was also observed that addition of calcium increases strength for 14 geopolymers cured at ambient conditions, while it reduces mechanical properties of geopolymer cured at elevated temperatures because the presence of calcium hinders the development of the three-dimensional network structure in the geopolymer gel [10]. The presence of both $\mathrm{CSH}$ and geopolymer gel in a geopolymer could have beneficial effects on strength because the CSH phase act like micro-aggregates for the geopolymer gel and forms a denser and more uniform binder [10]. In a recent study by Xu-Chen et al. [11], it was noted that calcium substantially increased setting of geopolymers with external $\mathrm{Si}$ addition, although formation of C-A-S-H gel was not confirmed. These studies were based on the extensive NMR studies. Pulgila and Mondal [12] worked on slag-flyash geopolymer system and proposed hardening due to precipitation of $\mathrm{C}-\mathrm{S}-\mathrm{H}$, and C-A-S-H geopolymer contributing to rapid hardening. This is in contrary to the fly ash based geopolymer where the formation of the above geopolymer gel is relatively slow. Their work was based on selective dissolution of the gel through acid leaching. In a separate study Mucsi et al. [13] made synergetic use of lignite based power plant 
fly ash and converter slag addition with water glass (as $\mathrm{Na} / \mathrm{Si}$ source) which was shown to give geopolymer reaction with a compressive strength as high as $20 \mathrm{MPa}$ and this can be used as concrete in civil construction. Moreover, the same author [14] carried out mechanical activation of fly ash and its enhanced effect on the geopolymerisation was revealed. A relationship was found between the geopolymer physical properties (compressive strength, density) and fly ash fineness (median particle size).

There is a lack of documented research involving geopolymeric reaction mechanisms occurring in natural systems like ore minerals consisting of calcium and alkaline minerals and in such systems, it is likely that both calcium silicate hydrate (C-S-H gel) and conventional S-Al-H gel geopolymeric reactions could be forming simultaneously. As a result, an investigation into the role of calcium in dictating the chemical mechanism will provide answers to the fundamental question as to whether two separate phases will be formed, or a new material will be produced.

In the present work, research is conducted with the addition of calcium (in the form of ground granulated blast furnace, GGBS) and lime (commercial variety) in iron ore mineral waste (iron ore tailings) system with fixed amount of sodium silicate (as constant source of sodium for geopolymeric reactions). It is pointed out, that this will lead to a number of reaction products, depending on the form of calcium present. It is anticipated that likely products to be formed will be $\mathrm{Si}-\mathrm{Al}-\mathrm{H}$ gel, $\mathrm{Ca}-\mathrm{Si}-\mathrm{H}$ gel, and $\mathrm{Ca}-\mathrm{Al}-\mathrm{Si}-\mathrm{H}$ gel.

Molar ratios of (Si/Al) and $(\mathrm{Ca} / \mathrm{Si})$, contribute to strength development and it is presumed that (Si/Al) contributes to short period strength development while $(\mathrm{Ca} / \mathrm{Si})$ ratio contributes to long period strength development. In the present study a mathematical model has therefore been proposed to identify the role each of them has for compressive strength development through the following expression:

$(\mathrm{Si} / \mathrm{Al})^{N 1}(\mathrm{Ca} / \mathrm{Si})^{N 2}=\mathrm{C}$ where $\mathrm{N} 1$ is an exponent of ( $\mathrm{Si} / \mathrm{Al})$ ratio and $\mathrm{N} 2$ is an exponent of $(\mathrm{Ca} / \mathrm{Si})$ ratio indicating short period and long period strength developments respectively, while $C$ is the compressive strength developed on keeping the samples for different extended time periods. Determination of values of $\mathrm{N} 1$ and $\mathrm{N} 2$ will give the role of $(\mathrm{Si} / \mathrm{Al})$ and $(\mathrm{Ca} / \mathrm{Si})$ in the strength development.

Another problem, for the comprehension of the geopolymeric molecular structures in the high iron containing compounds is the presence of excessive iron which debars one to use Nuclear Magnetic Resonance Spectroscopy (NMR) study. Therefore, one has to be satisfied with the mathematical relationship studies in the system.

In regard to the industrial application the present research explores the possibility of utilising iron ore mine waste for the production of ecofriendly bricks. These bricks are produced by mixing iron ore tailings (IOT), ground granulated blast furnace slag (GGBS), sodium silicate $\left(\mathrm{Na}_{2} \mathrm{SiO}_{3}\right)$, and lime hydroxide in definite proportions and forming the brick in a hand operated block making machine. The formed bricks were kept at room temperature for extended time periods after which their compressive strength was tested in an isostatic press (ISOTEK). This technology avoids firing procedure essential in normal brick manufacture with naturally available siliceous clay and is environment friendly.

\section{Materials and methods}

\subsection{Materials}

The materials used in this study include iron ore tailings, sodium silicate solution $\left(\mathrm{Na}_{2} \mathrm{SiO}_{3}\right)$, lime, ground granulated blast furnace slag (GGBS), and potable water. The mine tailings were received in sizes $<150 \mu \mathrm{m}$ to $2 \mathrm{~mm}$ from the Bellary mining area (BMM Ispat), Karnataka, India. The physical properties of the mine tailings were determined as per the standard (IS: 2720 part 3\&7). Table 1 shows the various physical properties of iron tailings. Ground granulated blast furnace slag (GGBS) is a byproduct of steel industry. The 
chemical composition of iron ore tailings and GGBS are given in Table below (Table 1).

Table 1. Chemical composition of the iron ore tailing and GGBS (in percentage quantities)

\begin{tabular}{|l|c|c|}
\hline Chemical composition & $\begin{array}{c}\text { Iron ore } \\
\text { tailings }\end{array}$ & GGBS \\
\hline Silica $\left(\mathrm{SiO}_{2}\right)$ & 9.02 & 34.16 \\
\hline Ferric Oxide $\left(\mathrm{Fe}_{2} \mathrm{O}_{3}\right)$ & 66.56 & 1.99 \\
\hline Alumina $\left(\mathrm{Al}_{2} \mathrm{O}_{3}\right)$ & 9.56 & 17.54 \\
\hline Calcium Oxide $(\mathrm{CaO})$ & 1.96 & 37.10 \\
\hline Magnesium Oxide $(\mathrm{MgO})$ & 2.12 & \\
\hline Manganese Oxide $(\mathrm{MnO})$ & 1.15 & \\
\hline Titanium Oxide $\left(\mathrm{TiO}_{2}\right)$ & 0.66 & 1.00 \\
\hline Potash $\left(\mathrm{K}_{2} \mathrm{O}\right)$ & & 0.31 \\
\hline Sodium Oxide $\left(\mathrm{Na}_{2} \mathrm{O}\right)$ & & 0.57 \\
\hline Loss on ignition $(\mathrm{LOI})$ & 8.9 & 0.1 \\
\hline
\end{tabular}

Fig. 1 and Fig. 2 give Scanning Electron photographs of the iron ore tailings and GGBS, respectively.

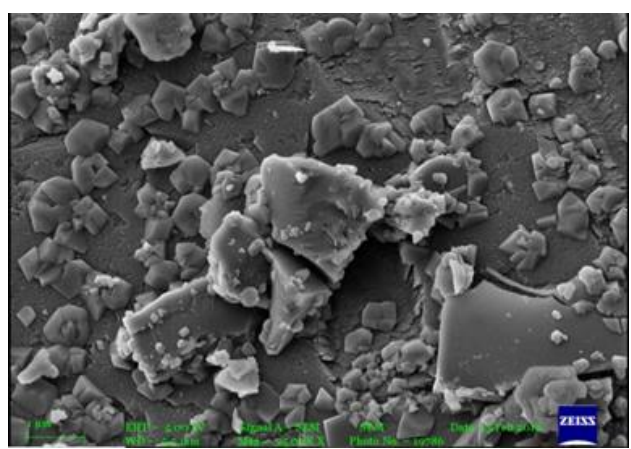

Figure 1. SEM Photograph of iron ore tailings

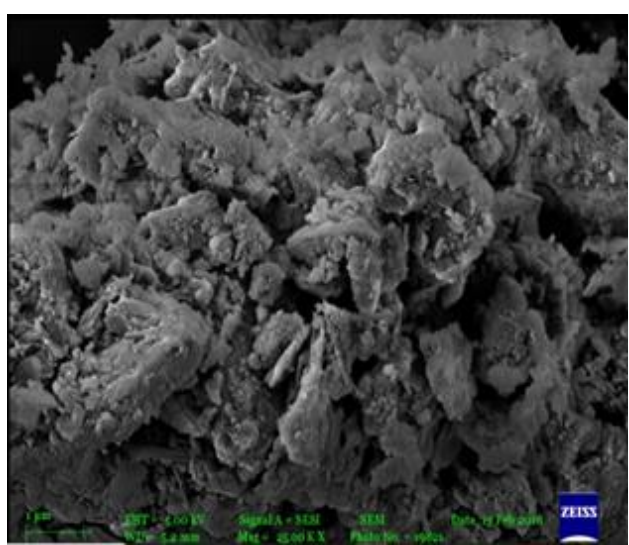

Figure 2. SEM photograph of GGBS
Fig. 3 and Fig. 4 give the $x$-ray diffraction patterns of both IOT and GGBS. It can be observed that in IOT, phases like kaolinite and calcite were also present as impurities of natural origin in addition to the main crystalline phase material hematite. GGBS showed a highly amorphous nature in XRD pattern and therefore it can be seen as a highly reactive phase to control the geopolymeric reaction.

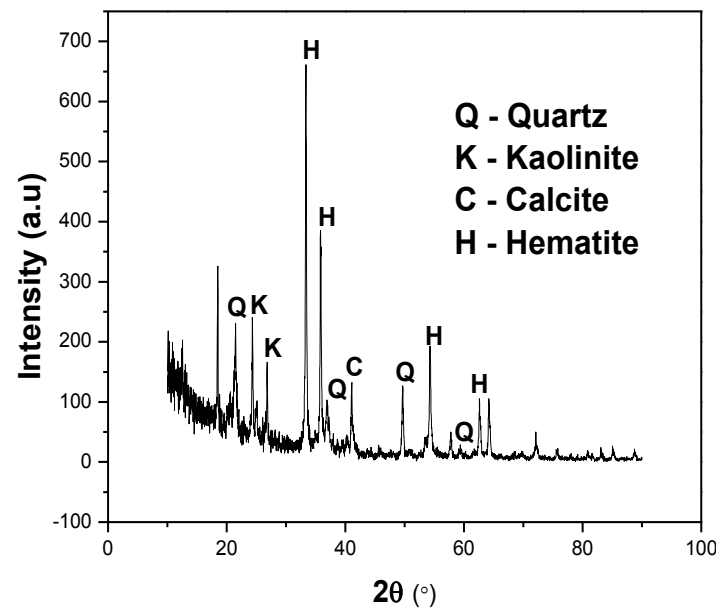

Figure 3. XRD pattern of iron ore tailings (IOT)

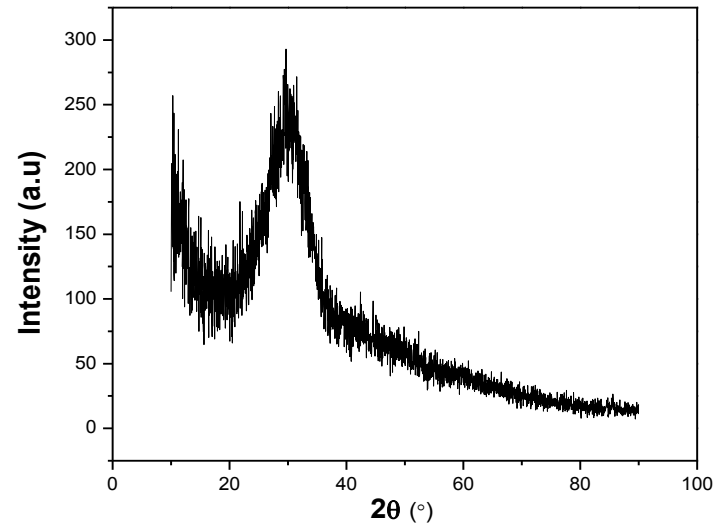

Figure 4. XRD pattern of GGBS

The lime used in this study was commercial and slaked in nature and the purity was more than $96 \%$. Sodium silicate used in this study was procured from a local sodium silicate manufacturer in liquid form (M/S Siltech) in concentration range of $3: 1$. 


\subsection{Preparation of brick samples}

For this study standard sized bricks $(230 \mathrm{~mm} \mathrm{x}$ $115 \mathrm{~mm} \times 75 \mathrm{~mm}$ ) were made by hand pressing. The variation of IOT was between $30 \%$ to $50 \%$ with increments of $5 \%$. While the amount of lime solution was kept fixed at $5 \%$ and sodium silicate concentration was fixed at $20 \%$. The addition of GGBS was proportionately decreased from $45 \%$ to $25 \%$ in a way that the total of IOT and GGBS for each composition was fixed at $75 \%$. Table 2 below shows the details of each individual composition.

Table 2. Mix proportions

\begin{tabular}{|c|c|c|c|c|}
\hline $\begin{array}{c}\text { Mix } \\
\text { designation }\end{array}$ & \multicolumn{4}{|c|}{ Mix proportions (\%) } \\
\hline & IOT & GGBS & $\mathrm{Na}_{2}$ SiO $_{3}$ & Lime \\
\hline B1 & 30 & 45 & 20 & 5 \\
\hline B2 & 35 & 40 & 20 & 5 \\
\hline B3 & 40 & 35 & 20 & 5 \\
\hline B4 & 45 & 30 & 20 & 5 \\
\hline B5 & 50 & 25 & 20 & 5 \\
\hline
\end{tabular}

\section{Results and discussion}

\subsection{Compressive strength}

The compressive strength test of the bricks was performed as per the IS:3495 standard. The compressive strength is expressed as:

Compressive strength $=\frac{\text { Maximum load at failure }}{\text { Area of bed surface }}$

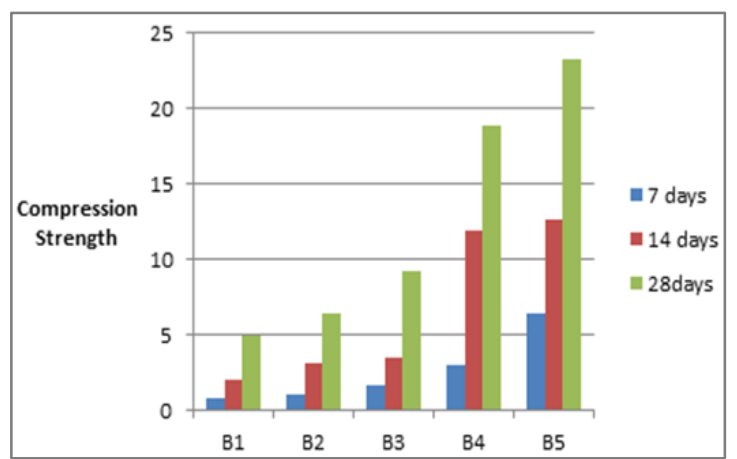

Figure 5. Compressive strength test data
Load was applied axially at a uniform rate of 14 $\mathrm{N} / \mathrm{mm}^{2}$ per minute until failure takes place. The samples were placed between $3 \mathrm{~mm}$ plywood sheets at the top and bottom of the surface of the bricks to avoid non-uniform distribution of load. The result of the compressive strength is given in Fig.6.

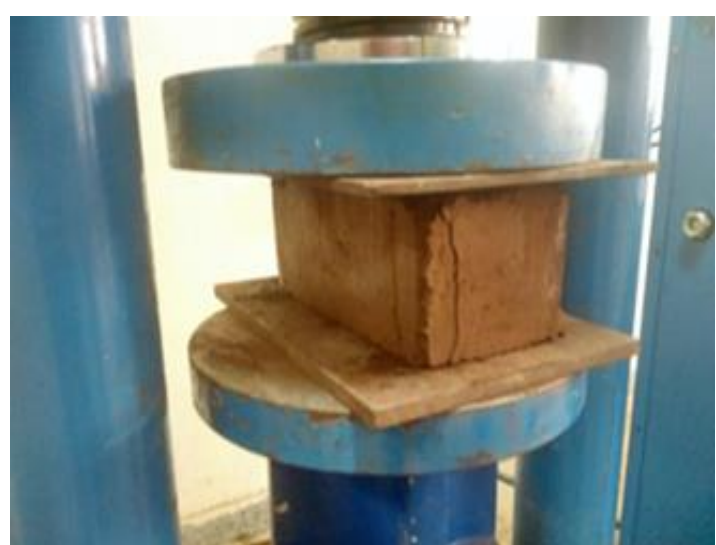

Figure 6. Compressive strength test of Brick Samples

\subsection{Density}

The density of the brick is an important parameter and is expressed as:

Bulk Density $=\frac{\text { Mass }}{\text { Volume }}$

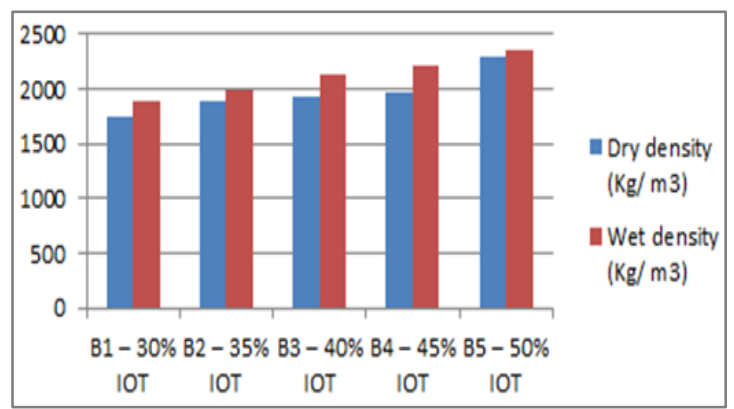

Figure 7. Dry density and wet density of samples

\subsection{Water absorption}

Test refers to the ability of absorbing water when materials are exposed to water. Water absorption data was obtained by immersion of samples in water for twenty four hours at room 
temperature and then they were wiped dry with a cloth and weighed immediately. The increase in weight is reported as the percentage gain in water. As per the IS:3495 good quality bricks should not absorb more than $20 \%$ water. The expression for water absorption $24 \mathrm{~h}$ is (in percentage):

Water absorption $=\frac{\text { Wet weight }- \text { Dried weight }}{\text { Dried weight }} 100$

Table 3. Water absorption test of bricks

\begin{tabular}{|c|c|}
\hline Brick designation & Water absorption \\
\hline B1 & 5.9 \\
\hline B2 & 7.5 \\
\hline B3 & 10.2 \\
\hline B4 & 12.7 \\
\hline B5 & 13.5 \\
\hline
\end{tabular}

3.4. Hardness test, soundness test and structure test - qualitative tests

The hardness test is required to detect the quality of the brick. Under this test, the brick surface is scratched with a solid and if the brick is unaffected, then the quality of the brick is considered good.

In soundness test two bricks are made to hit against each other holding them in both hands. If there is sharp metallic ringing sound, and the bricks do not break, then the quality of bricks is considered to be good.

In structure test a brick is visually inspected for presence/absence of any flows, cracks, or holes on the surface. The size, shape, and colour of the brick should also be randomly checked. A superior quality brick must poses sharp edges and corners and bright and even colour throughout.

\subsection{Relationship between (Si/Al) ratio and} $(\mathrm{Ca} / \mathrm{Si})$ ratio with compressive strength values

Table below gives the percentage of (Si/Al) and $(\mathrm{Ca} / \mathrm{Si})$ ratio in each individual samples and their relationship with strength parameters after 7 and 28 days.
Table 4. Percentage $(\mathrm{Si} / \mathrm{Al})$ and $(\mathrm{Ca} / \mathrm{Si})$ ratios with compressive strength

\begin{tabular}{|c|c|c|c|}
\hline $\begin{array}{c}\text { (Si/Al) } \\
\text { percentage } \\
(\mathrm{Y} \text { axis })\end{array}$ & $\begin{array}{c}\text { (Ca/Si) } \\
\text { percentage } \\
(\mathrm{Y} \text { axis })\end{array}$ & $\begin{array}{c}7 \text { days } \\
\text { strength } \\
(\mathrm{X} \text { axis })\end{array}$ & $\begin{array}{c}28 \text { days } \\
\text { strength } \\
(\mathrm{X} \text { axis })\end{array}$ \\
\hline 62 & 38 & 0.9 & 4.9 \\
\hline 63 & 37 & 1 & 6.5 \\
\hline 64 & 36.5 & 1.7 & 9.2 \\
\hline 64.6 & 35.3 & 3 & 11.9 \\
\hline 65.2 & 34.7 & 6.5 & 13.7 \\
\hline
\end{tabular}

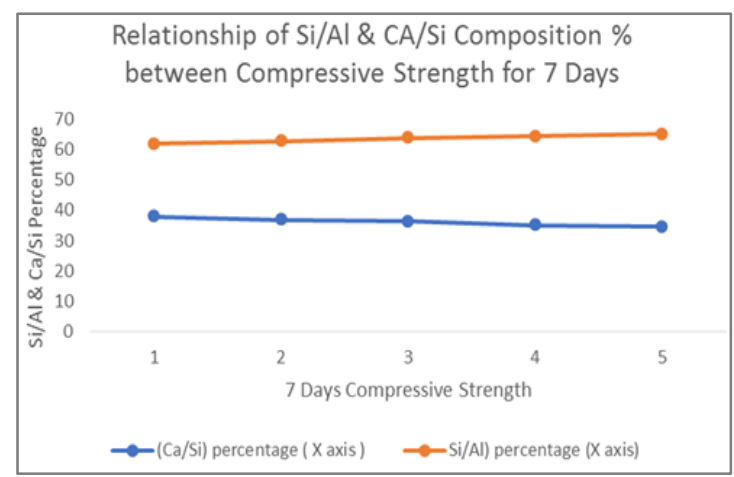

Figure 8. Relationship between (Si/Al) and (Ca/Si) ratio with compressive strength after 7 days

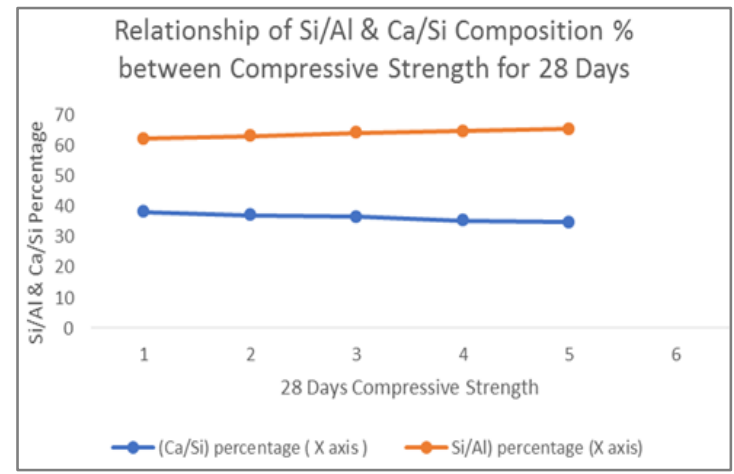

Figure 9. Relationship between (Si/Al) ratio and $(\mathrm{Ca} / \mathrm{Si})$ ratio with compressive strength after 28 days

\subsection{Finding out values of $\mathrm{Si}-\mathrm{Al}-\mathrm{H}, \mathrm{Ca}-\mathrm{Si}-\mathrm{H}$ and $\mathrm{Ca}-\mathrm{Si}-\mathrm{Al}-\mathrm{H}$}

Considering molar quantities of each chemicals present in the individual compounds the following equations give contributions of each:

(X) $\mathrm{Si}-\mathrm{A}-\mathrm{H}=X \mathrm{SiO}_{2}+X \mathrm{Al}_{2} \mathrm{O}_{3}$ 
(Y) $\mathrm{C}-\mathrm{S}-\mathrm{H}=\mathrm{YCaO}+\mathrm{Y \textrm {SiO } _ { 2 }}$

(Z) $\mathrm{C}-\mathrm{A}-\mathrm{S}-\mathrm{H}=\mathrm{Z} \mathrm{CaO}+\mathrm{Z} \mathrm{Al}_{2} \mathrm{O}_{3}+\mathrm{Z} \mathrm{\textrm {SiO } _ { 2 }}$

This gives on simplification:
(7) $\mathrm{SiO}_{2} \mathrm{~mol},(2)(\mathrm{X}+\mathrm{Z})=$ Total $\mathrm{Al}_{2} \mathrm{O}_{3} \mathrm{~mol}$, and (3)

(8) $\quad(\mathrm{Y}+\mathrm{Z})=$ Total $\mathrm{CaO} \mathrm{mol}$.

Table below gives the molar composition and their amount in each compositions.

Table 5. Values of $X$ (Si-Al-H mol), $Y$ ( $\mathrm{Ca}-\mathrm{Si}-\mathrm{H}$ mol) and Z (Ca-Si-Al-H mol)

\begin{tabular}{|c|c|c|c|c|c|c|c|c|c|}
\hline $\begin{array}{c}\text { Composition } \\
\text { No }\end{array}$ & $\begin{array}{c}\text { Total } \\
\text { silica } \\
\left(\mathbf{S i O}_{2}\right)\end{array}$ & $\begin{array}{c}\text { Mol } \\
\text { silica } \\
\left(\mathbf{S i O}_{2}\right)\end{array}$ & $\begin{array}{c}\text { Total } \\
\text { alumina } \\
\left(\mathrm{Al}_{2} \mathbf{O}_{3}\right)\end{array}$ & $\begin{array}{c}\text { Mol } \\
\text { alumina } \\
\left(\mathrm{Al}_{2} \mathbf{O}_{3}\right)\end{array}$ & $\begin{array}{c}\text { Total } \\
\text { calcia } \\
(\mathrm{CaO})\end{array}$ & $\begin{array}{c}\text { Mol } \\
\text { calcia } \\
(\mathrm{CaO})\end{array}$ & $\begin{array}{c}\text { Value } \\
\text { of } \mathbf{X} \\
(\mathbf{S}-\mathrm{A}-\mathrm{H})\end{array}$ & $\begin{array}{c}\text { Value } \\
\text { of } \mathbf{Y} \\
(\mathbf{C}-\mathrm{S}-\mathrm{H})\end{array}$ & $\begin{array}{c}\text { Value of } \\
\mathbf{Z} \\
(\mathrm{C}-\mathrm{A}-\mathrm{S}-\mathrm{H})\end{array}$ \\
\hline $\mathrm{B} 1$ & 27.91 & 0.465 & 10.76 & 0.105 & 22.08 & 0.394 & 0.07 & 0.36 & 0.037 \\
\hline $\mathrm{B} 2$ & 26.65 & 0.444 & 10.37 & 0.101 & 20.33 & 0.36 & 0.08 & 0.343 & 0.021 \\
\hline $\mathrm{B} 3$ & 25.39 & 0.423 & 9.96 & 0.097 & 18.53 & 0.330 & 0.093 & 0.326 & 0.004 \\
\hline $\mathrm{B} 4$ & 24.1 & 0.401 & 9.57 & 0.093 & 16.76 & 0.299 & 0.102 & 0.308 & $(-) 0.09$ \\
\hline $\mathrm{B} 5$ & 22.83 & 0.380 & 9.18 & 0.090 & 15.0 & 0.267 & 0.113 & 0.290 & $(-) 0.02$ \\
\hline
\end{tabular}

3.7. Finding out values of $\mathrm{N} 1$ and $\mathrm{N} 2$ from

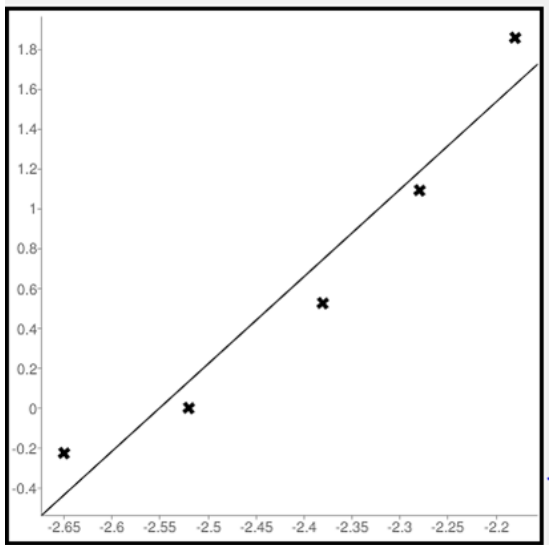

Figure 10. Correlation between (Si-Al-H) with compressive strength (positive correlation 99.0\%)

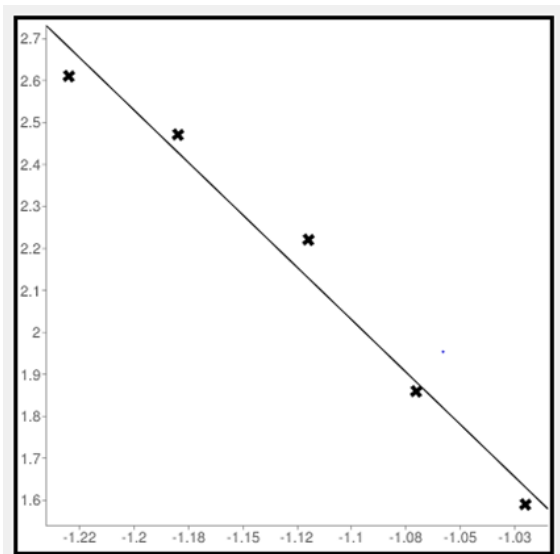

Figure 11. Correlation between (Ca-Si-H) with compressive strength (negative correlation $99.0 \%$ ) linear equations with two variables $\mathrm{N} 1$ and $\mathrm{N} 2$

Table below gives the values of $\mathrm{N} 1$ and $\mathrm{N} 2$ after solving quadratic equations comprising of (1) 30 and 35 percentage iron ore compositions; (2) 30 and 40 percentage iron ore compositions; (3) 30 and 45 percentage iron ore compositions; and (4) 30 and 50 percentage iron ore compositions. The individual values of N1 and N2 as calculated are given in the table below.

Table 6. Values of $\mathrm{N} 1$ and $\mathrm{N} 2$ after solving different quadratic equations formed from (30\% and $35 \%),(30 \%$ and $40 \%),(30 \%$ and $45 \%)$ and $(30 \%$ and $50 \%)$ iron oxide combinations

\begin{tabular}{|c|c|c|c|}
\hline $\begin{array}{c}\mathbf{3 0} \% \text { and } \\
\mathbf{3 5 \%}\end{array}$ & $\begin{array}{c}\mathbf{3 0 \%} \text { and } \\
\mathbf{4 0} \%\end{array}$ & $\begin{array}{c}\mathbf{3 0} \% \text { and } \\
\mathbf{4 5} \%\end{array}$ & $\begin{array}{c}\mathbf{3 0} \% \text { and } \\
\mathbf{5 0} \%\end{array}$ \\
\hline \multicolumn{4}{|c|}{7 days strength data } \\
\hline-7.61 & -8.49 & -8.88 & -9.55 \\
\hline-7.53 & -8.28 & -8.7 & -9.43 \\
\hline $\mathbf{3 0 \%}$ and & $\mathbf{3 0 \%}$ and & $\mathbf{3 0 \%}$ and & $\mathbf{3 0 \%}$ and \\
$\mathbf{3 5 \%}$ & $\mathbf{4 0} \%$ & $\mathbf{4 5 \%}$ & $\mathbf{5 0 \%}$ \\
\hline \multicolumn{4}{|c|}{28 days strength data } \\
\hline-2.55 & -1.73 & -3.03 & -1.56 \\
\hline-9.33 & -8.5 & -9.91 & -8.31 \\
\hline
\end{tabular}

The figures 12 and 13 indicate that the individual values of both $\mathrm{N} 1$ and $\mathrm{N} 2$ have little influence on compressive strength after 7 days while they exhibit a difference after 28 days such that $\mathrm{N} 1(\mathrm{Si} / \mathrm{Al})$ is always above $(\mathrm{Ca} / \mathrm{Si})$ values. 


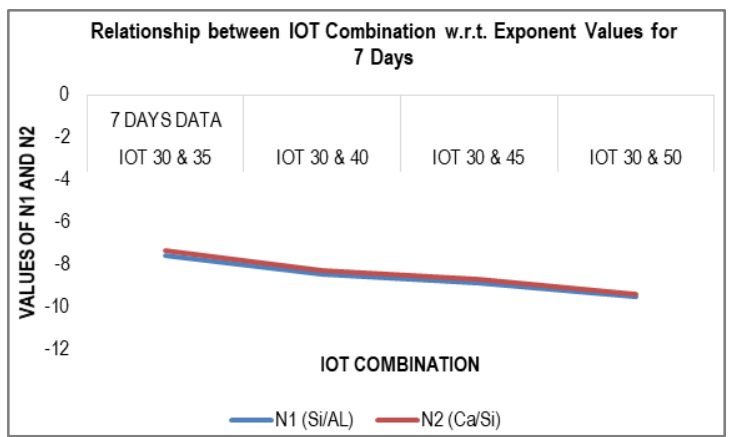

Figure 12. Relationship between exponent values N1 and N2 with compressive strength values after 7 days

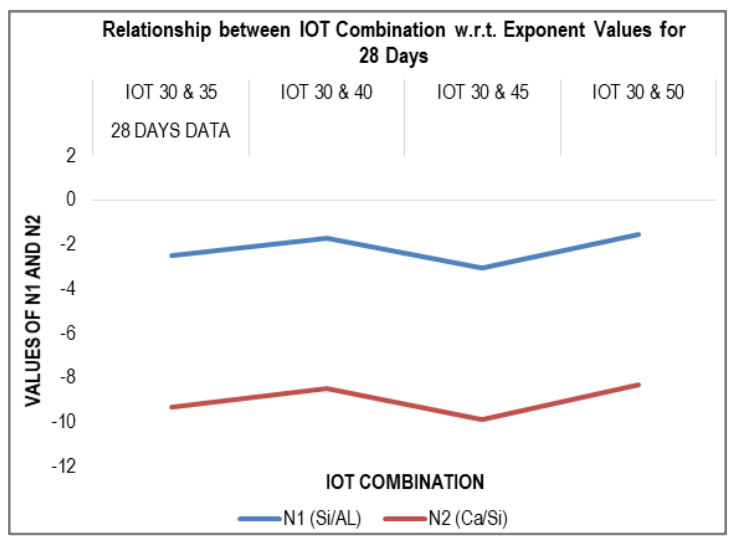

Figure 13. Relationship between exponent values $\mathrm{N} 1$ and $\mathrm{N} 2$ with compressive strength values after 28 days

\subsection{SEM Studies}

Fig.14 shows the gel formation in some of the samples soaked for 7 days and 28 days, respectively.

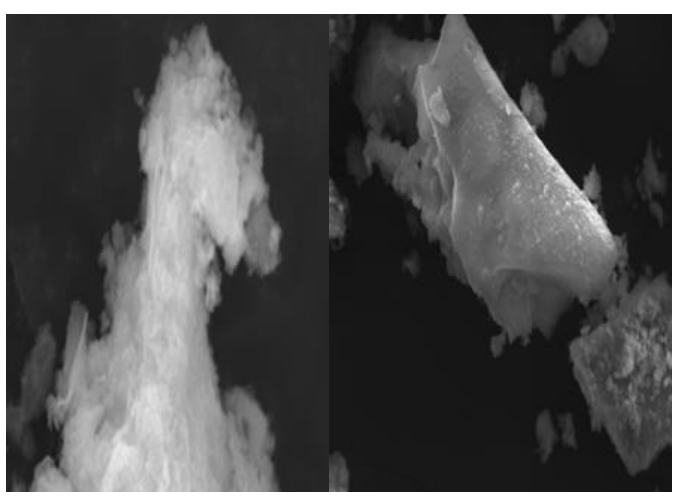

Figure 14. SEM images of samples indicating gel formation
Although formation of gel was evident in both the figures, it was difficult to differentiate whether they were formed from pure geopolymeric reaction from Si-Al system or a product formed from C-S-H system. Difficulties were encountered to identify them individually because of diffuse nature of the XRD pattern. Other sophisticated instrumentation should be used in future for analysis of such complex systems.

\section{Conclusion}

In iron ore tailing geopolymeric reaction, with addition of industrial wastes like ground granulated blast furnace slag, lime, and sodium silicate, a pronounced increase in compressive strength with increasing time period was observed. To explain the reaction mechanism behavior more intensively, individual relationship between (Si/Al) ratio and $(\mathrm{Ca} / \mathrm{Si})$ ratio with compressive strength values were plotted. It was observed that the compressive strength due to (Si/Al) ratio is always higher than that due to $(\mathrm{Ca} / \mathrm{Si})$ ratio. Subsequently, a mathematical relationship combining the abovementioned parameters, namely (Si/Al) and $(\mathrm{Ca} / \mathrm{Si})$, with compressive strength values were tried in the form of a logarithmic relationship. In this relationship, value of $\mathrm{N} 1$, is associated with (Si/Al) ratio and value of $\mathrm{N} 2$, is associated with $(\mathrm{Ca} / \mathrm{Si})$ ratio in a linear relationship with compressive strength values. Both $\mathrm{N} 1$ and $\mathrm{N} 2$ showed no variation with 7 days cured samples but exhibited significant variation with 28 days cured samples. The curve due to (Si/Al) was always above the curve due to $(\mathrm{Ca} / \mathrm{Si})$ in 28 days cured samples. Additional information on finding out individual molar amount of (Si-Al-H), (Ca-Si-H), and (Ca-Si$\mathrm{Al}-\mathrm{H}$ ) from the molar amounts of $\mathrm{SiO}_{2}, \mathrm{Al}_{2} \mathrm{O}_{3}$, and $\mathrm{CaO}$ present in each individual batches indicated a positive correlation between (Si-Al-H) gel with compressive strength, while a negative correlation between (C-S-H gel) with compressive strength. The correlation coefficients were greater than $99 \%$ in both cases. However, the correlation between CS-A-H with compressive strength could not be calculated as some of the data on the amount of $\mathrm{C}$ - 
A-S-H came out with negative values indicating no contribution.

It is thus concluded that in iron ore geopolymer samples with additions of both sodium silicate and calcia based materials, the effect of sodium silicate is more pronounced with its relationship with compressive strength as compared to calcia based materials addition.

\section{Acknowledgement}

The authors wish to acknowledge their thanks to the management of Christ (deemed to be university) and A.C.S College of Engineering for their help during different stages of this work.

\section{References}

[1] Davidovits, J., Davidovics, M. (1988) Geopolymer: Room-temperature ceramic matrix for composites. Ceramics Engineering Science Process 9 (7-8), 835-842.

[2] Davidovits, J. (1991) Geopolymers: Inorganic polymeric new materials. Journal of Thermal Analysis, 37, 1633-1656.

[3] Van Jaarsveld, J.G.S., Van Deventer, J.S.J., Schwartzman, A. (1999) The potential use of geopolymeric materials to immobilise toxic metals: Part II, Material and leaching characteristics. Minerals Engineering 12 (1), 75-91.

[4] Komarneni, S., Roy, R., Roy, D.M., Fyfe, C.A., Kennedy, G.J., Bothner-By, A.A., Dadok, J., Chesnick, A.S. (1985) 27A1 and 29Si magic angle spinning nuclear magnetic resonance spectroscopy of Al-substituted tobermorites. J. Mat. Sci., 20, 4209-4214.

[5] ASTM Standard Test Method for Compressive Strength of Hydraulic Cement Mortars (C 109), Annual Book of ASTM Standards, Vol. 04. 01, ASTM International, West Conshohocken, PA, (2003).

[6] Barbosa, V.F.F., MacKenzie, K.J.D., Thaumaturgo, C. (2000) Synthesis and characterisation of materials based on inorganic polymers of alumina and silica: sodium polysialate polymers. International Journal of Inorganic Materials, 2, 309-317.

[7] Tsuji, M., Komarneni, S., Malla, P. (1991) Substituted tobermorites: $27 \mathrm{Al}$ and $29 \mathrm{Si}$ MASNMR, cation exchange, and water sorption studies. J. Am. Cer. Soc., (74), 274279.

[8] Palomo, A., Krivenko, P., Gracia-loderio, I., Kavalerova, E., Maltseva, O., FernandezJimenez, A. (2014) Effect of activators on strength of hybrid alkaline cements. Materials construction, 64, 1-23.

[9] Yang, S., Navrotsky, A., Phillips, B.L. (2004) Study on synthesis of TPA silicalite from initially clear solutions of various base concentrations by in-situ calorimetry, potentiometry and SAXS. Chem. Mater., 16 (2), 210-219.

[10] De Jong, B.H.W.S., Schramm, C.H., Parziale, V.E. (1984) Polymerization of silicate and aluminate tetrahedral in glasses, melts and aqueous solutions- $v$, The polymeric structure of silica in albite and anorthite composition glass and devitrification of amorphous anorthite. Geochimica and Cosmochimica Acta, 48 (12), 2619-2629.

[11] Chen, X., Sutrinso, A., Strubble, L.J. (2018) Effect of Calcium on setting mechanism of metakaolin - based geopolymer. J. Amer. Ceram. Soc. 101, 957-968.

[12] Puligala, S., Mondal, P. (2013) Role of slag in microstructural development on hardening of fly ash - slag geopolymer. Cement and concrete Research,43, 70-80.

[13] Mucsi, G., Rácz, A., Molnár, Z., Szabó, R., Gombkötö, I., Debreczeni, A. (2014) Synergetic use of lignite fly ash and metallurgical converter slag in geopolymer concrete. Mining Science, 21, 43-55.

[14] Mucsi, G, Molnár, Z., Kumar, S. (2014) Geopolymerisation of Mechanically Activated Lignite and Brown Coal Fly Ash. International Conference on Mechanochemistry and Mechanical Alloying, Kraków, Poland, 2226. 


\title{
MOGUĆI MATEMATIČKI ODNOS IZMEĐU UTICAJA ODNOSA (Si/AI) I (Ca/Si) NA PRITISNU ČVRSTOĆU UZORKA JALOVINE DOBIJENE IZ RUDE GVOŽĐA NASTALU PRILIKOM GEOPOLIMERNE REAKCIJE
}

\author{
P. Das²\#, M. Beulah¹, N. Hossiney', U.M. Dunna', S. Kavitha² \\ ${ }^{1}$ Christ University, Faculty of Engineering, Kengeri, Bangalore, India \\ ${ }^{2}$ A.C.S College of Technology, Bangalore, India
}

(Primljen: 30. Avgust 2019.; Prihvaćen: 31. Oktobar 2019.)

\section{Izvod}

Prilikom geopolimernih reakcija u prisustvu jedinjenja bogatog krečom, parametar čvrstoće zavisi od molarnih odnosa (Si/Al) $i$ (Ca/Si), gde (Si/Al) odnos doprinosi kratkotrajnom povećanju čvrstoće, a (Ca/Si) odnos dugoročnom povećanju čvrstoće. U ovom radu se predlaže matematički model za identifikaciju uloga svakog pojedinačno na pojačanje čvrstoće kroz eksponencijalni matematički odnos, gde je N1 eksponent odnosa (Si/Al), a N2 eksponent odnosa (Ca/Si) što označava parametar kraćeg i dužeg porasta čvrstoće, respektivno, a C predstavlja pritisnu čvrstoću koja nastaje u uzorcima tokom različitih vremenskih perioda. Vrednosti za N1 i N2 se dobijaju rešavanjem linearnih jednačina za vrednosti (Si/Al) odnosa, (Ca/Si) odnosa i pritisne čvrstoće za različite eksperimentalne kompozicije.

Izračunate i izabrane količine natrijum silikata, natrijum hidroksida, kreča i granulovane šljake iz visokih peći (ggbs) koje se dodaju jalovini dobijenoj iz rude gvožđa ukazuju da su se vrednosti za N1 i N2 izjednačile nakon 7 dana od početka reakcije, ali je nakon 28 dana vrednost za N1 bila veća od vrednosti za N2. Može se doći do zaključka da je za dugoročno povećanje čvrstoće odnos (Si/Al) važniji od (Ca/Si) odnosa.

Ključne reči: Geopolimer; Cement; Izdržljivost; Kalcijum; Minerologija. 